\title{
Drug Kingpins and Their Helpers: Accomplice Liability under 21 USC Section 848
}

\author{
Sharon C. Lynch $\dagger$
}

One of the strongest weapons in the federal prosecutor's arsenal against drug offenders is the continuing criminal enterprise (CCE) statute. ${ }^{1}$ Commonly referred to as the drug kingpin statute, ${ }^{2}$ the law imposes severe mandatory minimum sentences ${ }^{3}$ and criminal forfeiture of assets ${ }^{4}$ upon a person convicted of engaging in a "continuing criminal enterprise." A person engages in a continuing criminal enterprise if he "occupies a position of organizer, a supervisory position, or any other position of management" of five or more people who act in concert to commit a continuing series of felony drug law violations. ${ }^{5}$

Recently, federal prosecutors have expanded the application of the CCE offense by bringing "aiding and abetting" charges against people who have aided a kingpin but who do not themselves meet the statutory definition of a kingpin. ${ }^{6}$ The assistance can take a

$\dagger$ B.A. 1988, Birmingham-Southern College; J.D. Candidate 1991, The University of Chicago.

121 USC \& 848 (1988).

2 The term "kingpin" is commonly used to describe a large-scale drug offender.

s 21 USC $\$ 848(\mathrm{a})$, the sentencing portion of the CCE, provides that any person convicted of the CCE offense "shall be sentenced to a term of imprisonment which may not be less than 10 years and which may be up to life imprisonment ... ", while second offenders are subject to a twenty-year minimum imprisonment. Section 848 (b) provides for mandatory life sentences for CCE offenders who are principal leaders or organizers of particularly large drug rings. Some have referred to this provision as the "super kingpin" statute.

1 21 USC $\S 853(\mathrm{a})$ (1988) provides that those convicted under $\S 848$ "shall forfeit to the United States . . . any property constituting, or derived from, any proceeds the person obtained, directly or indirectly, as the result of such violation," any property used in any way to facilitate the commission of the violation, and any property or contractual rights representing any interest in, or "affording a source of control over, the continuing criminal enterprise."

21 USC \& 848(d).

- While this strategy has not yet been employed in many cases, its use seems to be increasing. Given the current aggressive nature of drug law enforcement, it seems likely that if the aiding and abetting approach wins approval in the courts it will become more prevalent. For a criticism of the zealous pursuit of drug convictions in the 1980 s, see Steven Wisotsky, Crackdown: The Emerging "Drug Exception" to the Bill of Rights, 38 Hastings L J 889 (1987). 
number of forms, such as protecting the organization, ${ }^{7}$ acting as a supplier of drugs, ${ }^{8}$ or conducting transactions for an imprisoned kingpin. ${ }^{9}$ Federal prosecutors can significantly increase the prison term available for the convicted supplier of a drug organization if, in addition to charging him as a drug distributor, they can link him to a drug kingpin as an aider and abettor. ${ }^{10}$

The appellate courts have not unanimously embraced accomplice liability for CCE offenses, however. The Second Circuit has held that as a matter of law the CCE offense cannot be aided and abetted, ${ }^{11}$ relying on two distinct lines of argument. First, the court argued that the case fell within a well-established principle of accomplice liability that exempts participants in a criminal transaction who are necessary to the commission of a crime but who are left unpunished by the statute. ${ }^{12}$ Alternatively, the court argued that the legislative history of the kingpin statute established that Congress did not intend accomplice liability for the CCE offense. ${ }^{13}$ Under the Second Circuit's approach, aiding and abetting a CCE offense is simply not punishable as a separate crime.

In contrast, the Seventh Circuit has twice upheld CCE accomplice liability convictions. ${ }^{14}$ In doing so, it has explicitly rejected the Second Circuit's arguments. According to the Seventh Circuit, any difficulty with CCE accomplice liability is a policy problem for Congress, not the courts, to resolve. ${ }^{15}$ Under this approach, the CCE offense is subject to accomplice liability just as any other offense, absent explicit congressional exemption, would be.

This Comment first addresses the issue on which the Second and Seventh Circuits disagree-whether CCE accomplice liability can ever be imposed. However, the inquiry cannot end there. The judicial role in addressing the CCE accomplice liability question exceeds the issue of whether the accomplice liability statute ap-

7 United States v Ambrose, 740 F2d 505 (7th Cir 1984).

${ }^{8}$ United States v Pino-Perez, 870 F2d 1230 (7th Cir) (en banc), cert den 110 S Ct 260 (1989).

- United States v Amen, 831 F2d 373 (2d Cir 1987).

10 Perhaps even more important than the increased sentence, the CCE charge allows the government to seek forfeiture of the defendant's assets and even to freeze those assets before trial. 21 USC $\$ 853($ a). This forfeiture may extend even to funds set aside to pay defense attorney's fees. See Caplin \& Drysdale, Chartered v United States, 109 S Ct 2646 (1989).

11 Amen, 831 F2d 373.

12 Id at 381.

13 Id at 381-82.

14 Ambrose, 740 F2d at 505; Pino-Perez, 870 F2d at 1230.

1s Pino-Perez, $870 \mathrm{~F} 2 \mathrm{~d}$ at 1237. 
plies; it also includes deciding how it applies. Because of its unqualified rejection of accomplice liability for all CCE offenses, the Second Circuit has not treated this second issue. The Seventh Circuit, whose substantively opposite approach is similarly rigid, has not considered the proper limits of accomplice liability in the $\mathrm{CCE}$ context.

This Comment argues that the courts should resolve the conflict by developing a specialized accomplice liability standard for CCE cases. Section I sets forth the statutory background on the issue and describes the varying approaches of the circuit courts. Section II analyzes the arguments for and against CCE accomplice liability and discusses the proper role of the courts in dealing with the issue. This section concludes that neither the Second Circuit's wholesale rejection nor the Seventh Circuit's unlimited adoption of CCE accomplice liability is adequate. Section III proposes a new standard for CCE accomplice liability that attempts to resolve the problems presented by both approaches.

\section{The Current Status of CCE Accomplice Liability}

The question whether those who have aided a kingpin, but do not themselves meet the statutory definition of a kingpin, can be punished as accomplices involves the intersection of two statutes: 21 USC $\S 848$, which defines the CCE offense, and 18 USC $\S 2(a)$, which defines accomplice liability.

\section{A. The Drug Kingpin Statute: 21 USC § 848}

The CCE offense was passed as $\S 408$ of the Comprehensive Drug Abuse Prevention and Control Act of $1970 .^{16}$ The statute was designed primarily to provide prosecutors with a new tool for obtaining lengthy sentences for those who lead drug organizations. ${ }^{17}$ When enacted in 1970, it was the most punitive drug enforcement law. In fact, the CCE offense was the only section in the act incorporating a mandatory minimum sentence. ${ }^{18}$ To ensure that only

\footnotetext{
16 Pub L No 91-513, 84 Stat 1236 (1970), codified at 21 USC $\S 801$ et seq.

17 See Garrett v United States, 471 US 773, 781 (1985) (referring to $\$ 848$ as a "carefully crafted prohibition" to reach "the 'top brass' in the drug rings, not the lieutenants and foot soldiers").

${ }_{18}$ Comprehensive Drug Abuse Prevention and Control Act of 1970, HR Rep No 911444, 91st Cong, 2d Sess pt 1 at 4-5 (1970). The sentence for distribution of the most dangerous narcotic drugs, for example, was limited to imprisonment not to exceed fifteen years, while the CCE offense carried a minimum of ten years and maximum of life imprisonment. 21 USC § 841 (pre-1986 amendment); 21 USC § 848 (pre-1988 amendments). Amendments to the drug enforcement sentencing structure in 1986 and 1988 have made mandatory mini-
} 
professional criminals were subject to $\mathrm{CCE}$ liability, Congress used the technique it had developed for reaching organized criminal activity-the "complex statutory crime."19

Complex statutory crimes have two basic elements. First, the defendant must commit a traditional crime, such as robbery, extortion, or drug distribution. These crimes are generally referred to as the "predicate" or "underlying" offenses. Second, the defendant must meet a number of ancillary conditions. Not themselves criminal, these conditions are usually circumstances rather than actions. ${ }^{20}$ While the secondary conditions are substantive elements of the crime that a prosecutor must prove beyond a reasonable doubt, ${ }^{21}$ they are left largely undefined. ${ }^{22}$

In the case of the CCE offense, the required underlying crime is any drug-related felony. The secondary conditions are (1) a continuing series of violations; (2) action in concert with five or more persons; (3) occupation of a position of management or leadership with respect to those persons; and (4) receipt of substantial income from the CCE. ${ }^{23}$

Courts have interpreted the language of the CCE offense broadly so that the statute reaches those who are less than "top brass." 24 Courts have held, for example, that the supervision of five

mum penalties the rule rather than the exception. See, for example, 21 USC $\$ 841$ (1988) (incorporating mandatory minimum penalties for drug distribution offenses).

${ }_{19}$ Jeffers $v$ United States, 432 US 137 (1977). The most discussed and debated complex statutory crime is the RICO offense, 18 USC $\S \S 1961-68$ (1988). RICO was enacted, like the CCE offense, in 1970 . While the complex statutory crime is a relatively modern development, it has its roots in long-established federal crimes, such as the mail fraud statute, 18 USC $\S 1341$ (1988), and the Travel Act, 18 USC $\S 1952$ (1988), which rely upon jurisdictional elements to make an offense a federal crime.

${ }^{20}$ The RICO offense, for example, requires that the defendant participate in a "pattern" of racketeering activity and requires the involvement of an "enterprise." 18 USC § 1962. Another lesser-known complex statutory crime prohibits the operation of a gambling business that involves five or more persons and either operates continuously for thirty days or grosses $\$ 2,000$ in a single day. 18 USC $\S 1955$ (1988).

${ }^{21}$ Garrett, 471 US at 778 (the CCE offense "requires proof of additional facts, including concerted activity with five other persons, a supervisory role, and substantial income ...").

${ }^{22}$ In the case of the CCE statute, key terms such as "continuing series" and "substantial income" are not defined by the statute. This ambiguity was a major concern of the minority members of the House Committee who wrote additional comments. HR Rep No 91-1444 pt 1 at 84 (cited in note 18).

${ }^{23} 21$ USC § 848(d).

${ }^{24}$ United States v Moya-Gomez, 860 F2d 706, 745-49 (7th Cir 1988); United States v Becton, 751 F2d 250, 254-55 (8th Cir 1984) (holding that one need not be the dominant organizer or manager of a CCE to commit the offense). The CCE offense has been interpreted as expansively as the RICO offense but has attracted less attention, possibly because the CCE offense-unlike RICO-does not apply in the civil sphere. Other ambiguities in the 
persons need not have occurred simultaneously, ${ }^{25}$ that the five persons need not have been supervised on each of the underlying drug offenses ${ }^{26}$ that the jury need not agree on the identities of the five supervised persons ${ }^{27}$ and that circumstantial evidence may be sufficient to prove the defendant's receipt of substantial income. ${ }^{28}$ The cumulative effect of this expansive interpretation is that a drug kingpin conviction is not as difficult as the statutory language indicates. Like other complex statutory crimes, the CCE offense is a separate crime that is punished in addition to, not instead of, the underlying offenses. ${ }^{29}$

\section{B. Federal Accomplice Liability Law}

Federal accomplice liability arises under 18 USC $\S 2(a),{ }^{30}$ a general aiding and abetting statute that, absent explicit statutory language to the contrary, applies to all substantive federal crimes. ${ }^{31}$ Under this statute, anyone aiding or abetting the commission of a federal crime can be charged and punished as if he were a principal. The original accomplice liability statute had two purposes: abolishing the common law distinctions between different levels of accomplice liability ${ }^{32}$ and eliminating the need to attach an aiding and abetting section to each new substantive offense. ${ }^{33}$.

statute have been settled by the courts in a less expansive vein. For example, the continuing series of violations element has been satisfied by proof of at least three felony drug offenses. United States v Markowski, 772 F2d 358 (7th Cir 1985).

${ }^{25}$ United States v Barnes, 604 F2d 121, 157 (2d Cir 1979). In fact, the relationship between the kingpin and the five persons need not be a supervisor-subordinate one at all, United States $v$ Boldin, 818 F2d 771 (11th Cir 1987), and the supervision may be "indirect," United States $v$ Bond, 847 F2d 1233, 1236 (7th Cir 1988).

26 United States v Rhodes, 779 F2d 1019, 1026 (4th Cir 1985).

27 United States v Tarvers, 833 F2d 1068, 1074-75 (1st Cir 1987).

38 United States v Phillips, 664 F2d 971, 1034-35 (5th Cir 1981).

${ }^{29}$ Garrett, 471 US at 779. The courts have consistently upheld the statute's constitutionality against double jeopardy challenges. See Comment, Successive Prosecutions and the Continuing Criminal Enterprise: The Double Jeopardy Analysis in Garrett v. United States, 13 Hastings Const L Q 785 (1986).

so "Whoever commits an offense against the United States or aids, abets, counsels, commands, induces or procures its commission, is punishable as a principal." 18 USC § 2(a) (1988).

32 United States $v$ Rector, 538 F2d 223, 225 (8th Cir 1976). This general applicability is so well established that Amen, 831 F2d at 381, and United States $v$ Benevento, 836 F2d 60, 71 (2d Cir 1987), appear to be the only cases ever to hold 18 USC § 2(a) totally inapplicable to a federal criminal statute. Pino-Perez, $870 \mathrm{~F} 2 \mathrm{~d}$ at 1233.

"United States $v$ Kegler, 724 F2d 190, 200 (DC Cir 1984). The complex distinctions between various levels of accomplice liability that had developed under the common law are described in William Blackstone, 4 Commentaries on the Laws of England 34-40 (Chicago, 1979) (originally published 1769).

ss Before the original version of 18 USC $\S 2(a)$ was passed in 1909 , no federal statute 
Although federal accomplice liability is statutorily created, the general language used in 18 USC § 2(a) makes it necessary for the courts to rely on common law methods to develop the standards for its implementation. ${ }^{34}$ Since the statute was enacted, therefore, courts have shaped the doctrine of accomplice liability. The traditional standard for aiding and abetting requires that the defendant "in some sort associate himself with the venture, ... participate in it as something that he wishes to bring about, ... [and] seek by his action to make it succeed." ${ }^{35}$ Developed by Judge Learned Hand, this test is still generally accepted as the appropriate standard for imposing accomplice liability under 18 USC $\S 2(a){ }^{36}$

The widespread acceptance of the Hand test does not mean, however, that courts apply it invariably or mechanically in all cases. First, the courts have on occasion adjusted the Hand test in the context of a particular crime. For example, in the 1920s, an issue arose as to whether the merchants who sold raw materials to known bootleggers should be considered accomplices to the liquor offenses. In dealing with these "sale of goods" cases, ${ }^{37}$ the courts held that mere knowledge that the purchaser intended to use the product for illegal activity was not sufficient to support criminal liability ${ }^{38}$ However, the seller became legally culpable for the buyers' crimes if he "promote[d] their venture himself, ma[d]e it his own, and ha[d] a stake in its outcome." 39 Thus, the court required a standard of involvement significantly higher than that of the Hand test.

permitted the prosecution of one who aided and abetted another in the commission of a crime. Statutory authorization was necessary because of the long-established rule that there are no federal common law crimes. United States v Britton, 108 US 199, 206 (1883).

34 Morei v United States, 127 F2d 827, 830 (6th Cir 1942) (emphasizing that the statute's coverage would be very broad if common law standards were not incorporated).

${ }^{35}$ United States v Peoni, $100 \mathrm{~F} 2 \mathrm{~d}$ 401, 402 (2d Cir 1938). But see Backun v United States, 112 F2d 635, 636-37 (4th Cir 1940), which held a seller guilty as an accomplice although he would not profit personally from the crime and no intent to aid the principal had been shown. These two views coexisted until the Supreme Court expressly adopted the $\mathrm{Pe}$ oni standard in Nye \& Nissen v United States, 336 US 613, 619 (1949).

${ }^{\text {se }}$ See, for example, United States v Lema, 909 F2d 561, 569 (1st Cir 1990) (upholding conviction for aiding and abetting the possession of cocaine with intent to distribute); United States v Valencia, 907 F2d 671, 677 (7th Cir 1990) (same); United States v Poston, 902 F2d 90, 93 (DC Cir 1990) (upholding conviction for aiding and abetting possession of PCP).

${ }^{32}$ The sale of goods paradigm applies whenever a legal product is sold by a vendor to someone intending to use it for illegal activity. The same rationale would seem to apply, for example, to a gift shop selling drug paraphernalia, or a store selling burglar tools.

${ }^{38}$ See, for example, United States v Falcone, 109 F2d 579, 581 (2d Cir 1940).

ss Id. 
In addition to variations on the test itself, the courts have created exceptions to accomplice liability when the Hand test would lead to an absurd result or an outcome clearly inconsistent with congressional intent. ${ }^{40}$ Three such exceptions are well-established and widely accepted:41 first, victims of a crime may not be held liable for aiding and abetting even if their conduct substantially assisted in the commission of the crime; ${ }^{42}$ second, members of groups that the statute was enacted to protect will not be charged as aiders and abettors absent an affirmative legislative policy to the contrary; ${ }^{43}$ and, third, actors whose participation is necessary to commission of the substantive crime are not punished as aiders and abettors of that crime. ${ }^{44}$ The different tests and exceptions together represent judicial interpretation of 18 USC § 2(a) in light of the numerous federal criminal statutes to which accomplice liability can attach.

\section{CCE Accomplice Liability Decisions}

Although the kingpin statute was enacted in 1970, the intersection between it and the accomplice liability provision did not appear in practice until the 1980s. ${ }^{45}$ The federal appellate courts are divided as to whether accomplice liability should apply to the CCE offense. ${ }^{46}$ While the Second Circuit has concluded that as a matter of law the CCE offense can never be aided and abetted, ${ }^{47}$

10 The distinction between "exceptions" to accomplice liability and differences in standards is largely semantic. The only differences are that exceptions are couched as broader rules of interpretation, and the defendant has the burden of proving an exception applies.

11 These exceptions are explained fully in United States $v$ Southard, 700 F2d 1, 19-20 (1st Cir 1983).

12 Id at 19. Thus, the victim of blackmail who pays the money is not regarded as an accomplice.

4s Id at 19-20. For example, a woman transported willingly across state lines to engage in prostitution is not guilty of violating the Mann Act.

"Id at 20. The most common example of this exception is a statute that punishes prostitution without mentioning the customer. The customer could not be punished as an aider and abettor under that statute.

45 The 1986 amendments to $\S 848$ do not change any of the substantive language defining the crime. The only change related to the provision for mandatory life imprisonment of CCE violators if "such person is the principal administrator, organizer, or leader of the enterprise or is one of several such principal administrators, organizers or leaders," and the drug organization's drug law violations have either involved very large drug quantities or produced very large profits. 21 USC \& 848(b).

16 The Supreme Court has not yet addressed the CCE accomplice liability issue. Certiorari has been denied in all of these cases, including most recently Pino-Perez, $110 \mathrm{~S} \mathrm{Ct} 260$ (1989). Justices Brennan and White would have granted certiorari.

47 Amen, 831 F2d at 381-82; Benevento, 836 F2d at 71. 
the Seventh Circuit has held that aiders and abettors of a CCE offense can be punished as if they were principals. ${ }^{48}$

1. The Second Circuit position: Amen.

The Second Circuit held in United States $v$ Amen, ${ }^{49}$ and affirmed in United States $v$ Benevento, ${ }^{50}$. that accomplice liability as a matter of law cannot be imposed for aiding and abetting a drug kingpin under 21 USC $\S 848 . .^{51}$ In Amen, a group of defendants operated a heroin ring by telephone while the head of the organization was in a federal penitentiary. ${ }^{52}$ The kingpin received help in running his organization and keeping his subordinates under control from a fellow inmate and drug felon, Paradiso. Paradiso's assistance consisted mainly of telephone instructions to his own subordinates asking them to perform certain helpful services for the kingpin. ${ }^{63}$ For his role in assisting the kingpin's organization, Paradiso was convicted of aiding and abetting the CCE violation. ${ }^{.4}$

The Second Circuit unanimously reversed Paradiso's CCE conviction on two grounds. ${ }^{.5}$ First, the court held that aiding and abetting a CCE violation came within the principle of accomplice liability that "when Congress assigns guilt to only one type of participant in a transaction, it intends to leave the others unpunished for the offense." ${ }^{\text {"se }}$ According to the Second Circuit, by defining the

${ }_{18}$ Ambrose, 740 F2d at 508; Pino-Perez, 870 F2d at 1231. The CCE accomplice liability question was also alluded to by the Eighth Circuit in a footnote. United States $v$ O'Connell, 841 F2d 1408, 1425 n 9 (8th Cir 1988). The court assumed arguendo that an aiding and abetting instruction could be given on a CCE charge, citing Ambrose, but was not required to resolve the issue on appeal.

48 F2d at $381-82$.

$836 \mathrm{~F} 2 \mathrm{~d}$ at 71 .

81 The decision in Benevento relies almost exclusively on the analysis in Amen and does not offer any new analysis of the issue. Therefore, the discussion in this section is based on the Amen opinion unless otherwise indicated.

${ }^{52}$ Amen, 831 F2d at 375-76. For more details, see the lower court opinion, United States $v$ Vasta, 649 F Supp 974 (S D NY 1986). Amen was a large and complicated drug organization case that raised a number of issues on appeal. This Comment deals only with the conviction for aiding and abetting the CCE.

ss Amen, 831 F2d at 376-78.

s4 Id. Paradiso received a twenty-year prison sentence for this conviction, to be served consecutively with a twenty-year sentence for conspiracy to distribute and possession with intent to distribute heroin.

ss For an effective pre-Pino-Perez discussion of the weaknesses of the Amen decision see Comment, United States v. Amen: Aiding and Abetting Kingpins, 11 Harv J L \& Pub Pol 501 (1988).

${ }^{86}$ Amen, 831 F2d at 381 (citing Gebardi $v$ United States, 287 US 112, 123 (1932)). 
CCE offense as leadership of the enterprise, Congress "necessarily exclud[ed] those who do not lead."

The second and potentially more persuasive argument in Amen was that courts should uphold Congress's intent to create an exception to the accomplice liability statute for the CCE offense. ${ }^{58}$ The court recognized the dearth of direct evidence of such an intent, yet concluded that

[w] hile the legislative history makes no mention of aiders and abettors, it makes it clear that the purpose of making CCE a new offense rather than leaving it as sentence enhancement was not to catch in the CCE net those who aided and abetted the supervisors' activities, but to correct its possible constitutional defects by making the elements of the CCE triable before a jury. ${ }^{58}$

Thus, the Second Circuit would treat the CCE offense more like a sentence enhancement measure than a substantive offense.

2. The Seventh Circuit position: Ambrose and Pino-Perez.

Before the Amen decision, the Seventh Circuit held in United States $v$ Ambrose ${ }^{60}$ that one could be convicted of aiding and abetting a CCE offense. In Ambrose, a group of ten Chicago policemen protected two drug organizations from police interference and helped eliminate their competitors over a period of years. The court held that these defendants could be punished as aiders and abettors under the CCE statute. Under generally applicable principles of accomplice law, said the court, employees of the CCE cannot be punished as aiders and abettors, although persons not directly connected with the enterprise can. ${ }^{61}$ Therefore, once the factual determination was made that the policemen were non-employees, the only remaining issue was sentencing.

After Amen, the Seventh Circuit reaffirmed its position in United States $v$ Pino-Perez, ${ }^{62}$ an en banc decision that widened the split between the two circuits. In Pino-Perez, the defendant was the sole supplier of drugs to the kingpin's organization. He was not an employee of the CCE and therefore under Ambrose could be classified an aider and abettor. In upholding the supplier's con-

${ }^{87}$ Id.

ss Id at 381-82 (citing HR Rep No $91-1444$ pt 2 at 84 (cited in note 18)).

so Id at 382 .

60 $740 \mathrm{~F} 2 \mathrm{~d}$ at 508 .

61 Id. For discussion of the reasons why employees cannot be aiders and abettors of the CCE, see text at notes $80-82$.

${ }^{82} 870$ F2d 1230. 
viction as an accomplice, the Seventh Circuit reevaluated and affirmed its opinion that neither the language of the kingpin statute, its legislative history, nor the aiding and abetting statute barred a conviction for aiding and abetting a CCE. The court reaffirmed its earlier distinction, holding that while "the kingpin's employees are not aiders and abettors, ... the supplier of the kingpin's drugs may be."'63

\section{Arguments for and Against CCE Accomplice Liability}

In reaching their conflicting interpretations, the Second and Seventh Circuits focused on different elements of the problem of accomplice liability. The Seventh Circuit relied primarily on a statutory language argument, while the Amen court focused on congressional intent. This section examines both arguments and also evaluates the sentencing irrationality argument raised by Judge Easterbrook in his Pino-Perez dissent. After finding that none of these approaches adequately address the problems that CCE accomplice liability raises, the section concludes by arguing that accomplice liability precedent allows courts to fashion special tests for unusual statutes like the CCE provision.

\section{A. The Statutory Argument for Liability}

For Judge Posner and the Seventh Circuit majority in PinoPerez, whether CCE accomplice liability can ever be imposed is a matter of statutory interpretation. The federal accomplice liability statute applies to all substantive federal crimes. ${ }^{64}$ Therefore, the court must simply decide "whether violation of the federal 'kingpin' statute ... is 'an offense against the United States' within the meaning of the federal aider and abettor statute." fense is a substantive federal crime. ${ }^{68}$ Thus, at first glance, it ap-

\footnotetext{
${ }^{63}$ Id at 1233.

64 United States v Sopczak, 742 F2d 1119, 1121 (8th Cir 1984); United States v Jones, 678 F2d 102, 105 (9th Cir 1982).

Bs Pino-Perez, 870 F2d at 1231.

${ }^{66}$ Garrett, 471 US at 779 . This conclusion was not as obvious as it appears. The CCE statute began as a sentence enhancement provision. The original bill allowed the prosecutor, after obtaining a conviction for a felony drug offense, to ask the court to classify the defendant as a "dangerous special offender." HR Rep No 91-1444 pt 2 at 81 (cited in note 18). The criteria for this classification were very similar to those required under the CCE statute, and had the same goal of reaching the repeat "professional" drug offender. A special drug offender, like the CCE offender, would be subject to much harsher penalties than if convicted for the underlying offense alone. The substantive CCE offense was created largely to accomplish the same objective without causing potential constitutional problems under the confrontation clause. The main concern was that when making the special offender determina-
} 
pears clear that the offense can be aided and abetted. In fact, as the court pointed out, Amen was the first case to hold that 18 USC $\S 2$ (a) was completely inapplicable to a federal criminal statute. ${ }^{67}$

The general applicability of 18 USC $\S 2$ (a) supports the argument that inquiry into congressional intent is unnecessary. "The question is not whether section 2(a) is applicable-it always is. . . " 88 The automatic applicability of the statute means that Congress never has to address the accomplice liability issue when enacting a new substantive offense. ${ }^{69}$ Legislative silence is deemed to incorporate accomplice liability law, including the judicial doctrines for its application. Judge Posner concludes, "it was not Congress's purpose in making the operation of a continuing criminal enterprise a separate offense to bring section 2(a) into play. But such is never Congress's purpose in creating a new offense." "70 Accomplice liability is presumed under federal law to apply to a statute unless there is "an affirmative legislative policy" to create an exemption. ${ }^{71}$ Allowing a statute-by-statute inquiry into Congress's intent would introduce "great uncertainty into federal criminal law."72 Thus, for the Seventh Circuit, the question of whether accomplice liability could be imposed for a kingpin offense was a fairly easy case of applying existing law.

The Pino-Perez court did seem somewhat troubled by the unfairness that might arise in determining whether a particular defendant is an aider and abettor. The court determined, however, that common law standards of accomplice liability would be sufficient to prevent injustice. ${ }^{23}$ For example, the court recognized that

tion, the judge would have available information normally inadmissible at trial and witnesses whom the defendant had no opportunity to cross-examine. Despite its beginnings as a sentence enhancement measure, however, the legislative history of $\$ 848$ clearly indicates that it was intended to create a new substantive offense. For a detailed discussion of the debates leading to the inclusion of both methods to punish kingpins, see Garrett, 471 US at 783. The section-by-section analysis in the House Committee report refers to punishment "upon conviction for that offense" and to "convictions under this section." HR Rep No 91-1444 pt 1 at 50 (emphasis added). From this language, "the intent to create a separate offense could hardly be clearer." Garrett, 471 US at 782. This status as a separate offense means that it is subject to all statutes generally applicable to federal offenses, including in particular the accomplice liability statute.

${ }^{82}$ Pino-Perez, 870 F2d at 1233.

se Id.

-2 See Case Note, The Scope of Accomplice Liability under 18 USC \& 2(b), 31 Case W Res L Rev 386, 392 (1981).

${ }^{70}$ Pino-Perez, $870 \mathrm{~F} 2 \mathrm{~d}$ at 1233 (emphasis in original).

7 Id at 1234 (quoting United States v Falletta, 523 F2d 1198, 1200 (5th Cir 1975)).

72 Id.

73 Judge Posner explained that in any case where liability is truly undeserved, the standards of common law accomplice liability would not be satisfied. Id at 1234-35. 
employees of a CCE clearly fall within an established exception to accomplice liability. ${ }^{74}$ In addition, the Ambrose court recognized that, at least in some cases, not imposing accomplice liability would frustrate the purpose of the $\mathrm{CCE}$ law. The policemen in Ambrose protected the organization; if they could not be punished as aiders and abettors, the deterrent effect of the kingpin statute would be reduced. ${ }^{75}$ The Seventh Circuit concluded that accomplice liability for such participants is proper: "Persons who assist a kingpin but are not supervised, managed, or organized by him do not fit any [recognized] exceptions, and we are reluctant to create [another]." "78

The Seventh Circuit did not, however, assert that accomplice liability would always comport with the purpose of the kingpin statute. Rather, the court maintained that any problems in application that could not be handled by these traditional doctrines must be corrected by Congress, not the courts. "If the mesh between [the two statutes] is imperfect-which it is-still the judicial cure that we attempted in Ambrose, and the even more drastic cure that our respected colleagues in the Second Circuit attempted in Amen are, we believe, even worse than the disease."77

Judge Posner's argument provides a straightforward and accurate reading of the statutory language. The simplicity of the argument, however, reflects a view of the CCE accomplice liability problem that is too narrow. The Pino-Perez decision fails to recognize that a second effect of a generally applicable accomplice liability statute is that the standards for imposing accomplice liability are not tailored to the specific crime, except to the extent the courts themselves limit its application. As discussed below, the courts historically have sought to perfect the intersection between the accomplice liability provision and the substantive offense at issue.

\section{B. The Congressional Intent Arguments Against Liability}

The Second Circuit "cured" the CCE accomplice liability problem by concluding that such liability can never be imposed. It used two rationales to support this conclusion. The court first argued that aiding and abetting a CCE violation comes within an established exception to accomplice liability, and second that Con-

\footnotetext{
74 Id at 1231-32.

75 Ambrose, $740 \mathrm{~F} 2 d$ at 508.

${ }^{76}$ Pino-Perez, 870 F2d at 1232.

77 Id at 1237.
} 
gress intended to create an exception to the accomplice liability statute when it passed the CCE statute.

\section{The Gebardi exception.}

The Second Circuit's first argument in Amen was that all CCE accomplice liability cases fall within a traditional exception: persons whose existence is necessary to the commission of the crime but who are left unpunished by the statute cannot be aiders and abettors. This exception was first established in Gebardi $v$ United States, ${ }^{78}$ a landmark case in accomplice liability law. The Gebardi prosecution was based upon the Mann Act, which criminalizes the interstate transportation of women for prostitution or other immoral purposes. ${ }^{79}$ The question was whether the women who were illegally transported could be convicted as aiders and abettors of their own transportation under the Mann Act. The Court held that Congress, by structuring the statute as it did, did not intend to punish the transported women. In other words, Congress realized that there would be women involved and apparently chose not to criminalize their participation in the transaction. Thus, concluded the Court, Congress would not want its decision not to punish the women to be circumvented by an automatically applicable accomplice liability law.

The Amen court was correct to apply this principle to the employees of the kingpin who make up the five-person enterprise. The employees cannot be prosecuted as aiders and abettors because the language of the statute itself clearly contemplates their existence but does not provide for their punishment. ${ }^{80}$ The Gebardi principle, however, does not apply to the facts in Amen. As a non-employee accomplice, the Amen defendant's participation in the organization's crimes was not contemplated by Congress when it drafted this statute. It is not in any way necessary to the commission of a CCE offense that the kingpin have a major supplier or any other non-employee help. To apply the Gebardi analysis here would be equivalent to holding that the person who makes the plans and acquires the vehicle for a Mann Act violation cannot be an aider and abettor simply because the transported women cannot be. The Gebardi exception would completely overwhelm the rule. That is not the principle that Gebardi represents. ${ }^{81}$ Only

\footnotetext{
73 287 US 112,123 (1932).

7818 USC § 2421 et seq (1988).

So See also Pino-Perez, 870 F2d at 1231.

s1 The court might have been attempting to use the Gebardi analysis to show that a
} 
the five or more persons supervised by the kingpin are necessary to the violation and only they fall under this exception. ${ }^{82}$

The Amen court tried to bolster its interpretation of the statute by claiming that because the statute punishes only those who lead CCE offenses Congress necessarily did not intend to punish those who do not lead..$^{83}$ This argument fails because the basic premise of accomplice liability is that some who do not commit the substantive offense still require punishment. Accomplice liability is, by definition, imposed upon someone who has not committed the criminal act itself. For example, under a statute that defines murder as killing, a person may aid and abet a murder without actually killing anyone. To hold otherwise-as the Amen court apparently would-would virtually eliminate accomplice liability altogether.

\section{Specific congressional intent as to CCE.}

The Amen court's second rationale was that Congress intended to exempt CCE offenses from the accomplice liability statute, even if none of the traditional exceptions to accomplice liability applied. This argument would be convincing if there were significant evidence that Congress had such an intent. The legislative history, however, is devoid of discussion of accomplice liability. The court found this intent in more imaginative ways.

The court's approach to congressional intent has two major flaws. First, it begins with the wrong premise: that Congress must intend for 18 USC $\S 2$ (a) to apply to a particular crime when it is passed in order for accomplice liability to attach. In fact, the opposite premise is correct. Automatic application to all new substantive offenses was a major purpose behind enactment of a general

defendant who could not have committed the principal offense cannot aid and abet that offense. However, recent decisions have clearly held that such a restriction on accomplice liability does not exist. See, for example, United States v Standefer, 610 F2d 1076, 1085 (3d Cir 1979) (holding that 18 USC $\S 2(a)$ is intended to punish aiders and abettors whether or not they are legally capable of committing the substantive violation). For example, only political officials can violate some bribery statutes, yet an aide who arranges a deal can be convicted of aiding and abetting the bribery violation.

s2 The Gebardi exception is not, however, without any application to the CCE accomplice liability question. It and the other judicially created exceptions to accomplice liability are important because they demonstrate the concern of the courts to reflect accurately congressional intent when applying accomplice liability doctrine and the flexibility with which they can apply 18 USC $\S 2(a)$.

${ }^{83}$ Amen, 831 F2d at 381. 
aiding and abetting statute..$^{84}$ As the Amen court itself admitted, ${ }^{85}$ when two statutes interact the normal presumption is that Congress was aware of the effects of the prior statute at the time it passed the later one. ${ }^{86}$ Therefore, the burden of establishing a clear congressional intent must be on the party arguing that accomplice liability should not apply. Without convincing evidence to demonstrate this intent to preempt accomplice liability law, a court cannot legitimately decide that Congress did not intend the law to apply. To reason otherwise would completely frustrate the motive behind the enactment of 18 USC § 2(a). Therefore, if Congress were truly silent on this question, the court would have to allow accomplice liability in CCE offenses.

The second major defect in the Amen court's reasoning is that it could not marshal any convincing legislative history to support its position. Rather than concede that Congress did not express any intent on accomplice liability, the court attempted to locate this congressional intent in snippets of the legislative history, including comments by minority members of the House committee. For example, the court quoted the concerns of "several members of the committee" that "this section still contains serious objections" including the failure to define a "continuing series of violations" and "substantial income or resources." Other statements expressed concern that mandating a minimum penalty would make it difficult to find a minor offender guilty. ${ }^{87}$ From these statements, the court inferred that the CCE offense was designed to resemble a sentence enhancement measure, not a substantive offense. The problem, however, is that the court's evidence of congressional intent consists of statements that were adopted only by a minority of the congressional committee reporting the bill. ${ }^{88}$ That the statements the court relies on do not in any way refer to aiding and abetting only highlights the frailty of the court's analysis.

If these criticisms of the Amen decision are correct, one may ask what led the court to question the imposition of CCE accomplice liability. First, and most obviously, the court was concerned about the line-drawing problems inherent in the distinction between employees and others. The court queried, "How does one determine whether a person is an employee or third party? What

\footnotetext{
84 See text at notes 31-33.

${ }^{85}$ Amen, 831 F2d at 382 . The court said that it could not reconcile the two statutes and therefore must choose to remain faithful to "the plain terms and clear intent of $\S 848$ " at the expense of 18 USC $\$ 2(a)$.

Be See Lorillard v Pons, 434 US 575, 581 (1978).

${ }^{87}$ Amen, 831 F2d at 382 (quoting HR Rep No 91-1444 pt 1 at 82-85 ("Additional Views" of Representatives Moss, Dingell, Adams, and Eckhardt) (cited in note 18)).

${ }^{88}$ Id at 382.
} 
of the businessman who leases a boat to a CCE engaged in importation? Or his lawyer?"89 The Amen court was reluctant to read Gebardi narrowly because it doubted the workability of the distinction between employees and other aiders. ${ }^{\circ 0}$ While this distinction may be unclear at the margin, however, the difficulty in application cannot support judicial refusal to apply a validly enacted congressional statute.

Although not insignificant, this problem is solely practical. For most traditional crimes, the Hand test fits comfortably with an intuitive sense of when someone has actually aided in the commission of a crime. For example, in a bank robbery, both the Hand test and.common sense suggest that the getaway driver has aided and abetted the crime, but the teller who hands over the cash has not. In contrast, complex statutory crimes are not as easily resolved under the Hand test. The fact that in some cases the Hand test will be difficult to apply or the distinction between employees and non-employees will be difficult to draw does not justify eliminating liability altogether. ${ }^{91}$

Second, apart from the practical line-drawing problems, the Amen court criticized CCE accomplice liability in substance. The Second Circuit was concerned that in practice the imposition of CCE accomplice liability will be arbitrary, no matter how accurately judges may draw the traditional lines. The imperfect operation of the traditional accomplice liability test in the case of the CCE offense will lead to an incoherent legal regime where equally culpable drug offenders are punished very unequally.

For example, seller A and seller B may each sell the same amount of drugs in the same neighborhood at the same price, yet one may be punished as a CCE offender, while the other is not. The sole difference may be that A has a single major customer who meets the statutory definition of a kingpin, while B sells to twenty smaller customers. This outcome seems arbitrary because it separates the severity of the punishment from any notion of personal culpability or the amount of harm caused to society. Such arbitrary distinctions between offenders are inconsistent with the purposes of the CCE statute. The Amen court thus correctly feared that traditional principles of accomplice liability will not ade-

8 Id.

"o See id (calling the distinction between employees and others "totally unworkable" and "without support in the legislative history").

91 See Pino-Perez, 870 F2d at 1234-35, where Judge Posner effectively answers the "slippery slope" argument. 
quately protect against this arbitrariness and differentiate between those who merit sentences of CCE severity and those who do not.

\section{The Statutory Conflict Argument}

Dissenting in Pino-Perez, Judge Easterbrook also argued against the imposition of $\mathrm{CCE}$ accomplice liability, ${ }^{82}$ but for quite different reasons. He was concerned about the effect of CCE accomplice liability on the rest of the drug sentencing structure: according to Judge Easterbrook, the problem with CCE accomplice liability is that one statute would be applied in a way that would seriously undermine the operation of the statutory scheme as a whole. ${ }^{93}$

Judge Easterbrook was particularly troubled by the application of CCE accomplice liability to sellers of drugs. These offenders are already covered by 21 USC $\S 841$, which provides a wide range of specified penalties for various types and amounts of drugs. ${ }^{94}$ "To treat an aider and abettor as a kingpin on the authority of $\S 2(\mathrm{a})$ is to demolish the graduated structures under $\S 841$." ${ }^{95}$ Judge Easterbrook concluded, "Forced to choose between damage to the language of $\S 2$ (a) ... and damage to the language and structure of both $\S 848 \ldots$ and $\S 841 \ldots$, we should preserve as much as possible of $\S \S 841$ and $848 .{ }^{\prime 96}$

The concern for statutory coherence is in some ways more compelling than the Second Circuit's intent argument. However, the argument is subject to similar criticism. Judge Easterbrook fails to present enough evidence of conflict to support overriding the clear language of the statutes. According to Judge Easterbrook,

92 It is not clear from Judge Easterbrook's dissent whether he would hold CCE accomplice liability inapplicable in all cases or only when sellers punishable under $\S 841$ are involved. Pino-Perez, $870 \mathrm{~F} 2 \mathrm{~d}$ at 1241 (Easterbrook dissenting) (concluding, that "the CCE statute covers suppliers only if they have organizations over which to reign").

is The Supreme Court expressed some of the same concerns in deciding that violations of 21 USC $\S 846$, the drug conspiracy statute, and 21 USC $\S 848$ could not be punished cumulatively. Jeffers $v$ United States, 432 US 137, 156 (1977) ("Section 848 itself reflects a comprehensive penalty structure that leaves little opportunity for pyramiding of penalties" from other drug offenses.). The Court did not extend this reasoning, however, to cumulative penalties under $\$ 848$ and the underlying drug offenses. Garrett, 471 US at 779 ("Congress intended the CCE provision to be a separate criminal offense which was punishable in addition to, and not as a substitute for, the predicate offense.").

* 21 USC $\$ 841$.

os Pino-Perez, 870 F2d at 1238 (Easterbrook dissenting). 21 USC \& 841 deals with drug distribution offenses and uses quantity as the trigger for increasing penalties. It "reaches anyone who is trafficking in certain quantities of narcotics-including mid-level dealers." United States $v$ Power, 881 F2d 733, 739 (9th Cir 1989).

98 Pino-Perez, $870 \mathrm{~F} 2 \mathrm{~d}$ at 1240-41 (Easterbrook dissenting). 
imposing CCE accomplice liability would create a "crazy-quilt pattern of liability" that would significantly undermine the deterrent effects of the graduated sentencing structure of 28 USC $\S 841 .^{87}$ His point is well taken; yet his solution surpasses his criticism. While there may be conflicts between the purposes of these two statutory schemes in certain cases, these conflicts are not inherent in every, perhaps even most, cases of CCE accomplice liability; they do not require eliminating all accomplice liability for the $\mathrm{CCE}$ offense.

The driving force behind Judge Easterbrook's dissent is the perceived irrationality in imposing CCE accomplice liability. According to this view, the irrationality threatens to undermine the entire federal drug sentencing structure by creating an incoherent sentencing regime. If there is an important policy furthered by differentiating between the sale of one kilo and ten kilos of drugs, it is undermined by catapulting the smaller seller to the top of the sentencing structure simply because he sold his supply to a kingpin.

Judge Easterbrook's definition of the problem is not quite accurate, however, to the extent that it ignores Congress's intent to punish the sellers of equal amounts and types of drugs quite differently if either seller or buyer is the leader of a CCE. The CCE statute makes it clear that quantity of drugs is only one criterion of culpability in drug cases. The existence of a CCE offense demonstrates that Congress considered promotion of a drug enterprise to be an evil apart from the drug transactions themselves. The essence of the CCE offense is that the seller of five kilos who fits the CCE criteria should face higher sentences than the seller of five kilos who does not fit the criteria.

The irrationality in sentencing arises not because sellers of equal amounts of drugs will sometimes be punished unequally, but because often those who are punished as CCE aiders and abettors have not aided the kingpin as a kingpin, in which case increased punishment does not further the congressional intent in the CCE statute to deter the formation of these organizations. Judge Easterbrook's argument more strongly supports a modification of the Hand test for accomplice liability in a CCE offense than it does a blanket refusal to apply 18 USC \& 2(a) to the CCE offense.

${ }^{87}$ Id at 1238 (Easterbrook dissenting). 
D. The Role of Courts in Developing Accomplice Liability Law

The difficulty with the approach taken by both circuits is their characterization of the CCE accomplice liability issue as a simple yes or no question. Judge Posner's criticism of the Second Circuit's reasoning in Amen was correct, but he took such a narrow view of the case that he did not give enough weight to the Second Circuit's concerns about arbitrary outcomes in individual cases. On the other hand, neither Judge Easterbrook nor the Amen court addresses the converse of the irrationality and arbitrariness problems: what about the aider and abettor who has done everything in his power to support the existence of a CCE, and has been effective in doing so? Can a court credibly assert that Congress intended that he be lightly punished? The elimination of accomplice liability in all CCE cases might be no more faithful to congressional intent than the view criticized by the Amen court. This section argues that both circuits' failure to inquire into the results of their decisions is inconsistent with the traditional role of the courts in developing accomplice liability doctrine.

Accomplice liability under 18 USC § 2(a) "has never been applied mechanically; its scope depends on the structure and functions of the substantive statute." ${ }^{98}$ Thus, the real question to be resolved is when CCE accomplice liability should be imposed. This question can be resolved by the courts through the normal process of developing accomplice liability doctrine. Indeed, the courts have often been required to determine how 18 USC § 2(a) should interact with a particular substantive statute; the Hand test itself reflects a judicial interpolation of 18 USC $\S 2$ (a) in the context of possession of counterfeit money. ${ }^{99}$ The general language of the accomplice liability statute makes such determinations unavoidable.

This judicial role is particularly important when a mechanical application of the Hand test to a particular substantive statute would lead to irrational or unjust results. The Hand test requires in general terms that the defendant (1) associate himself with the venture, (2) participate in it as something he wishes to bring about, and (3) seek by his action to make it succeed. ${ }^{100}$ This traditional accomplice liability standard is difficult to apply to complex crimes like the CCE offense, however. ${ }^{101}$ The Supreme Court has recog-

${ }_{98}$ Id at 1239 (Easterbrook dissenting).

90 Peoni, $100 \mathrm{~F} 2 \mathrm{~d}$ at 401.

300 Id at 402.

101 Problems with applying the accomplice liability crimes to the RICO offense have received more attention and raise similar issues. See Note, Aiding and Abetting the Invest- 
nized in the double jeopardy context that standard principles of criminal.law may not always be readily transposed from the "classically simple situation" to "the multilayered conduct, both as to time and to place," involved in CCE cases. ${ }^{102}$ If the Hand test yields irrational results in the CCE context, then the courts should not woodenly apply it to these cases.

The courts' reluctance to modify the standards for applying 18 USC $\S 2(a)$ to the CCE offense is surprising, given their reliance upon Gebardi and other cases where the courts did just that. All the exceptions to accomplice liability were judicially created in response to the perception that a mechanical application of the Hand test, itself a judicial creation, to a particular set of cases would be illogical. There was no statutory basis for the result in Gebardi; the court simply determined that any other result would be fundamentally inconsistent with the legislative policy embodied in the statute. Thus, the court developed a rule that limited accomplice liability to those cases in which its application was deemed consistent with the relevant legislative provisions. ${ }^{103}$ Such a judicial course seems consistent with the courts' role as interpreters of the general language used in legislation.

In addition to the broad judicially created exceptions, courts have also created special standards for certain types of offenses. For example, the sale of goods cases ${ }^{104}$ raised the particular problem of when knowing assistance became aiding and abetting. In response, the courts developed a special "stake in the venture" standard designed to address that specific problem. Likewise, courts have made less explicit adjustments in applying accomplice liability standards to other areas such as securities fraud ${ }^{105}$ and drug possession. ${ }^{106}$

ment of Dirty Money: Mens Rea and the Nonracketeer Under RICO Section 1962(a), 82 Colum L Rev 574 (1982).

${ }^{102}$ Garrett, 471 US at 789. In Garrett, the Court rejected a direct application of the "lesser included offense" principles of double jeopardy to the CCE offense. While the Court did not explain why the principle should not be so transposed, the rationale must be that the structure of a complex crime makes mechanical application of basic principles illogical. ${ }^{103}$ If Gebardi arose for the first time in the Seventh Circuit today, to be consistent with Pino-Perez the court would presumably hold that the problem with the statute was for Congress to resolve. The Second Circuit, on the other hand, being equally reluctant to consider a middle ground, would probably hold that the Mann Act could never be aided and abetted.

${ }^{104}$ See text at notes 37-39.

${ }^{105}$ See Note, Liability for Aiding and Abetting Violations of Rule 10b-5: The Recklessness Standard in Civil Damage Actions, 62 Tex L Rev 1087 (1984).

${ }^{108}$ Several circuits have taken a broad view of a "community of criminal intent" to hold that a drug supplier can be convicted for aiding and abetting the recipient's possession with 
The history of federal accomplice liability law demonstrates that courts are not bound to apply the same standards in all cases and to all defendants. In passing a general accomplice liability law, Congress left to the courts the task of crafting a full doctrine of accomplice liability. As with any federal criminal law, the courts must apply the general law to the specific facts of the various cases. Courts have developed the terse language of 18 USC \& 2(a) into an elaborate set of tests and exceptions. While a court might seek to resolve the imperfect fit between the aiding and abetting and the kingpin statutes by either prohibiting accomplice liability in all cases (Second Circuit) or by generally embracing it (Seventh Circuit), courts can also take a middle ground by altering the test or creating a new exception. The courts have the latitude to look for solutions to the problems raised by CCE accomplice liability without choosing an all-or-nothing solution.

\section{A New Accomplice Liability Standard For the CCE OFFENSE}

Both solutions offered by the circuit courts will lead to unsatisfactory results in some cases. The Seventh Circuit provided an accurate reading of the statutory language, but its blanket approach gives rise to the arbitrariness and sentencing irrationality concerns raised by the Second Circuit and by Judge Easterbrook. The Second Circuit's wholesale rejection of CCE accomplice liability, on the other hand, ignores the statutory mandate and underlying legislative policy decisions. While no legal standard can resolve all the difficulties of a complex issue, the courts should adopt a standard specifically designed to combat these problems. The remainder of this Comment argues that the courts should adopt the following standard for CCE accomplice liability: a defendant aids and abets a CCE offense when he intentionally supports the kingpin's supervision of the continuing criminal enterprise.

This standard is designed to alleviate the concerns about the arbitrariness and rationality of CCE accomplice liability without neglecting congressional intent. This section develops the two principal elements of the proposed standard-each of which deals with one of the concerns raised by the courts-and applies the standard to a series of hypothetical fact patterns drawn from actual cases. 


\section{A. Intent to Aid the Enterprise}

Under the traditional doctrine of accomplice liability, the defendant must possess two types of mens rea. ${ }^{107}$ First, the accomplice must have a mental state with respect to the substantive offense. In general, this aspect of the mens rea requirement is determined primarily by the mens rea required for commission of the substantive offense. ${ }^{108}$ However, under federal law the accomplice need not have the same intent as the principal if they have a "community of unlawful intent." 109 For example, the mens rea of aiding and abetting murder is that one must share the principal's intent to kill or at least have some knowledge that the intent of the principal is to kill. ${ }^{110}$

The second aspect of the accomplice's mens rea is his mental state toward the actions in aid of the crime. The aiding and abetting statute itself uses words that refer to this intent, and Judge Hand incorporated this reading of the statute into his formulation of the test. ${ }^{111}$ Thus, the Hand test requires that the defendant act with an intent to aid the principal's criminal venture.

Once again, however, traditional formulations prove difficult to apply to the CCE offense. ${ }^{112}$ At a minimum, the intent standard for CCE accomplice liability must include knowledge that the kingpin is in fact a kingpin. Without a knowledge requirement, a defendant's punishment would be determined arbitrarily by the identity of the person with whom he happened to become involved. ${ }^{113}$ Even the Seventh Circuit has indicated that knowledge

107 Wayne R. LaFave and Austin W. Scott, Jr., Criminal Law § 6.7 at 579-81 (West, 2d ed 1986) (accomplice liability exists when the accomplice intentionally encourages or assists another in the commission of a crime as to which the accomplice has the requisite mental state).

${ }^{108}$ United States $v$ Beck, 615 F2d 441, $448-49$ (7th Cir 1980) (in order to satisfy the association prong of the Hand test, "there must be evidence to establish that the defendant shared in the criminal intent of the principal"'). See generally LaFave and Scott, Criminal Law $\$ 6.7$ at $580-81$ (cited in note 107).

100 Beck, 615 F2d at 449.

${ }^{110}$ LaFave and Scott, Criminal Law $\$ 6.7$ at 581 (cited in note 107).

111 "The words used [in the aiding and abetting statute]-even the most colorless, 'abet'-carry an implication of purposive attitude" towards the venture. Peoni, 100 F2d at 402.

112 For a general discussion of the difficulties in applying accomplice liability mens rea to "circumstance" offenses, see Note, The Mens Rea of Accomplice Liability, 61 S Cal L Rev 2169 (1988).

113 In most cases, this standard will be easily met. Knowledge can be shown by circumstantial evidence. United States $v$ Valle-Valdez, 554 F2d 911, 914 (9th Cir 1977). Thus, any type of close, continuous relationship between the kingpin and the defendant would probably support an inference of knowledge. Further, the defendant could not purposefully avoid 
of the kingpin's status is necessary to establish aiding and abetting of a CCE offense. ${ }^{114}$

A simple knowledge standard, however, would not adequately address the concern that equally culpable defendants will be punished unequally. Consider two drug middlemen, $A$ and $B$. The neighborhood kingpin, who is well known to both $A$ and $B$, needs a supplier on a fairly regular basis. Any supplier would love to have his business; he chooses, however, to deal exclusively with A. A, of course, is glad to have the business, yet has no particular interest in the kingpin's success per se. Under a knowledge standard, A would be in a difficult position. He must choose his buyers carefully or he will face a much higher criminal liability. This result in $\mathrm{CCE}$ cases seems inconsistent with Congress's desire to create an exceptional penalty for a certain class of drug offenders, those who lead a CCE.

The Hand test does seem to impose an intent requirementthat the defendant seek by his actions to make the venture succeed-but it is not clear what this means. In the CCE context, the venture is defined as the continuing criminal enterprise. ${ }^{115}$ The Seventh Circuit, however, implied that large and/or repeated sales of drugs to a particular customer can raise the inference of intent to help the venture succeed. If the intent to make one sale succeed is not sufficient to trigger liability, it is difficult to see why having repeat customers, without more, invokes greater culpability. In response, one might argue that the use of repeated dealings as evidence of intent is necessary to reach those who involve themselves in and actively promote the kingpin's affairs, and reap the benefits. Intent, after all, must almost always be shown by a proxy. ${ }^{116}$ The question is what that proxy should be.

such knowledge and then claim ignorance. United States $v$ Valencia, 907 F2d 671, 679 (7th Cir 1990) (when the defendant pleads ignorance or the evidence raises the issue, the jury may appropriately be instructed that they may infer knowledge "from a combination of suspicion and indifference to the truth").

${ }^{114}$ Pino-Perez, $870 \mathrm{~F} 2 \mathrm{~d}$ at 1235 (whether a particular drug seller is an aider and abettor depends upon what he knows and what he wants).

${ }_{116}$ Id at 1235 . Even this definition remains an oversimplification because the notion of a CCE only exists by virtue of a statutory definition. Especially after the broad interpretation of the statutory requirements given by the courts, it is clear that an "enterprise" in any formal sense of the word need not exist. In a traditional crime, the "venture" is the criminal act itself. In a CCE offense, however, the relationship between the criminal acts and the crime is quite different. The crime in the CCE offense is a collection of relatively independent factors. The alleged aider and abettor has usually been involved in illegal transactions with the kingpin that constitute some of the predicate crimes for the CCE offense. This complexity makes the determination of what the venture is for purposes of the Hand test less than obvious.

${ }^{116}$ It is unlikely that a witness will testify that the defendant said one day, "I hope I'm 
The "venture" that the Hand test requires the defendant to aid must be the entire continuing criminal enterprise, not one, or even several, drug transactions. An appropriate proxy for this type of aid would thus focus on the nature of the accomplice's interaction with the kingpin, not its frequency. To this end, the courts can borrow from the sale of goods cases and ask, "Did the defendant have a stake in the continuing criminal enterprise?"117 Like the sale of goods cases, many CCE accomplice liability cases are knowing assistance cases. ${ }^{118}$ That is, the defendant knows of the principal's criminal plan and knows that he is helping to complete the crime, yet he has no particular interest in its eventual success.

This narrow application of the Hand test is necessary to effectuate the purposes of the CCE statute and of accomplice liability. In almost all CCE accomplice liability cases the defendant will have an illegal intent to commit the underlying act. Both he and the kingpin share the intent to engage in a drug sale. But a simple drug transaction is quite different from running a large-scale drug operation; so Congress concluded by making direction of a CCE a separate offense. The intentional aid sufficient to impose accomplice liability must be assistance intended to aid the CCE itself, not simply an intent to have particular transactions with the CCE succeed.

In practice, the stake in the enterprise standard would look to whether the defendant had acted in a particularly favorable way toward the enterprise. For example, a supplier who regularly gave a kingpin a price cut or made similar special arrangements would meet this standard. ${ }^{119} \mathrm{~A}$ defendant who could be shown to have a quasi-contractual relationship on favorable terms with the kingpin would also meet the standard. The only real difference, but an important one, is that normal "independent contractors" (day-to-day

\footnotetext{
helping this continuing criminal enterprise to succeed." See Beck, 615 F2d at 449 (criminal intent "may be inferred from the attendant facts and circumstances").

117 Note, 82 Colum L Rev 574 (cited in note 101), applies a similar analysis to the RICO statute.

${ }^{118}$ LaFave and Scott, Criminal Law $\$ 6.7$ at 581 (cited in note 107). For a list of hypothetical examples of knowing assistance cases, see Model Penal Code $\$ 2.06$, Comment b (ALI, 1985). Knowing assistance is defined as "lending assistance or encouragement to a criminal scheme toward which [one] is indifferent."

${ }_{119}$ Compare People v Lauria, 251 Cal App 2d 471, 480-81, 59 Cal Rptr 628 (1967) ("Inflated charges, the sale of goods with no legitimate use, sales in inflated amounts, each may prvide a fact of sufficient moment from which the intent of the seller to participate in the criminal enterprise may be inferred.") Note that in the CCE context, participation in the venture will likely involve discounted rather than inflated prices.
} 
suppliers, lawyers, accountants, landlords, etc.) would not be treated as aiders and abettors regardless of how much they knew about their customer. Only when they treated the kingpin in a preferred or special manner because of the CCE would they open themselves up to the severe liability imposed under the kingpin statute. ${ }^{120}$

Requiring that the defendant intentionally aid the enterprise largely alleviates the concern that equally culpable offenders will be treated differently. Under the proposed standard the defendant must make a conscious decision to involve himself more deeply with the kingpin than just dealing with him at arms' length.

\section{B. Aiding the Kingpin's Supervision of the CCE}

Adopting the proposed mens rea standard above would significantly alleviate the Amen court's concerns about fairness in imposing CCE accomplice liability. However, the intent requirement does little to address the second goal of the proposed standard: reducing the conflict between $\mathrm{CCE}$ accomplice liability and the structure of the other drug laws.

To reduce this conflict, the proposed standard requires that the defendant aid and abet the kingpin's supervision of the enterprise. ${ }^{121}$ Unless the supervisory element is aided and abetted, imposing CCE accomplice liability is inconsistent with the aim of the substantive statute and with the language of 18 USC $\S 2$ (a). Accomplice liability requires assistance to the commission of the substantive offense. Thus, in the case of a CCE, assistance must relate to the enterprise aspect (direction and supervision) of the offense, not to the predicate offense. This factor distinguishes the CCE offense from other drug crimes. If Congress had only been concerned with the size of the drug organizations, it would not have included the supervisory requirement. Instead, it would have made the offense similar to the RICO offense, which punishes all those who knowingly participate in the corrupt activities. ${ }^{122}$ Both the continuing series and substantial income requirements are designed primarily to reach significant participants in drug organizations. ${ }^{123}$ The structure of the statute and the discussion of purposes in the

120 These actors might still be guilty, of course, of other serious crimes.

121 The supervisory element of the CCE offense is the provision in 21 USC $\$ 848$ (d) which refers to one who "occupies a position of organizer, a supervisory position, or any other position of management" within the enterprise.

12218 USC \& 1962.

123 See text at note 17 . 
legislative history make it clear that the CCE statute's application was to be limited to the leadership role.

Even if congressional intent were unclear on this point, there is another powerful argument for requiring the aiding and abetting of the supervision element of the $\mathrm{CCE}$ offense. Only by requiring that the defendant's conduct promote the supervision of the CCE can the courts prevent CCE accomplice liability from undermining the purposes of the structure of $\S 841$-Judge Easterbrook's concern. Imagine, for example, two drug dealers-A and B-each with a kilogram of cocaine to sell. A sells his supply to the neighborhood kingpin, while $\mathrm{B}$ sells his product directly to neighborhood teenagers. If this were a regular pattern, A would be subject to much higher penalties than $B$ under the CCE statute. It is difficult to see any rational relationship between the difference in sentences and the purposes of the CCE offense, and such a result would largely eliminate the quantity-based structure of drug punishments.

Requiring that the supervisory element be aided and abetted eliminates the irrationality problem because the supervisory element makes kingpins kingpins; Congress created the CCE offense to penalize the leaders of such enterprises. Thus, it is those who help kingpins in their role as supervisor or manager who truly aid a kingpin in committing the CCE offense. ${ }^{124}$ The Second Circuit argued that the CCE statute meant to punish only those who lead. This statement is technically correct, but the court stops its analysis one step short; the court should have said that Congress meant to punish as aiders and abettors only those who helped someone to lead.

Several circuits have already adopted the rule that when a particular element of a crime triggers the imposition of a higher penalty, this aggravating element must be aided to invoke accomplice liability. ${ }^{125}$ In the case of the CCE offense, in which the supervisory element of the complex crime is central to the offense and to the statutory purpose, aiding and abetting liability should not be imposed unless the defendant has furthered that element.

${ }^{224}$ For example, it is quite plausible that without the involvement of the aiding and abetting policemen in Ambrose, the organization would not have existed at all; at the very least, it would have come to an earlier demise.

126 United States v Fischel, 686 F2d 1082, 1087-88 (5th Cir 1982); United States v Jones, 678 F2d 102, 105 (9th Cir 1982). For convictions overturned on this basis, see also United States v Longoria, 569 F2d 422, 425 (5th Cir 1978); United States v Jackson, 526 F2d 1236, 1237 (5th Cir 1976). This proposition does not enjoy unanimous support in the circuits. See, for example, United States $v$ Wesson, 889 F2d 134, 135 (7th Cir 1989). 


\section{Applying the New Standard}

To appreciate the difference the proposed accomplice liability standard might make, it is helpful to examine its effect in paradigm cases. The following hypothetical scenarios, based on the facts of the major cases, illustrate application of this standard.

Case 1 (Pino-Perez): $\mathrm{X}$, a large-scale drug supplier, makes a continuing series of sales to $\mathrm{Y}$, a drug kingpin. $\mathrm{X}$ is the sole supplier of drugs for Y's organization. $X$ knows that $Y$ runs a substantial drug distribution network. There is no apparent relationship between $\mathrm{X}$ and $\mathrm{Y}$ other than these business dealings, and $\mathrm{X}$ does not give $\mathrm{Y}$ any preferred treatment because of the venture.

Result: Under the proposed standard, X would not be liable as an aider and abettor of Y's continuing criminal enterprise. Even if $X$ had given special benefits to $Y$, he would not be an aider of the CCE because he did not help $\mathrm{Y}$ in supervising it.

Case 2 (Ambrose): $\mathrm{X}$ is a policeman. $\mathrm{He}$ receives payments from Y, a known drug kingpin, in return for preventing Y's arrest. $\mathrm{X}$ accomplishes this result by refusing to respond to citizen complaints about Y's organization, by warning $Y$ of impending police raids, and by not disclosing to the police department the information he has gathered about Y's organization. In fact, $\mathrm{X}$ also helps protect Y's turf against encroachment by intimidating potential competitors.

Result: X could clearly be convicted of aiding and abetting the drug kingpin under the new standard. His involvement with the kingpin is more than a series of business transactions; he clearly has a stake in the enterprise's continued success. In addition, he satisfies the second requirement of aiding the kingpin's leadership. By preventing the kingpin's arrest and by keeping out competitors, $\mathrm{X}$ has helped Y remain at the head of his organization. X's assistance in Case 2, sufficient to invoke accomplice liability, is substantively different from that in Case 1, because of the direct link between X's conduct and Y's ability to manage and supervise the CCE. Multiple sales of drugs (Case 1), as long as they are on "market" terms, do not further the leadership of a CCE, while police protection facilitates direction of a large-scale illegal enterprise, the crux of the CCE offense.

Case 3 (Benevento): $\mathrm{X}$ is an acquaintance of $\mathrm{Y}$, a drug kingpin. $Y$ is convicted of another offense and sent to prison. In order to continue his drug operations, $\mathrm{Y}$ must have assistance from people on the outside. $X$ helps $Y$ consummate several drug deals by following Y's instructions given in code on the prison telephone. 
Result: Once again, $\mathrm{X}$ satisfies the first prong of the test; he is not making a mere business deal. He has made himself indispensable to the kingpin's operation and must expect some. special reward. This case is not clear-cut because where the kingpin has no other way to continue his activities, the person who helps him continue them also helps him continue his leadership of the organization. While the aid given in this case is not necessarily critical to the kingpin's continued leadership of his organization, it does seem likely to contribute significantly to it. Thus, liability in this case seems to coincide with the purposes of the CCE statute and is also unlikely to lead to irrational distinctions between equal offenders. ${ }^{126}$

\section{CONCLUSION}

The proposed standard for imposing CCE accomplice liability allows for a principled compromise between the extreme positions of the Second and Seventh Circuits. It recognizes the legitimacy of punishing aiders and abettors of CCEs, while avoiding the major problems inherent in applying accomplice liability to the CCE offense. This standard is more workable in the CCE context than the traditional Hand test, and comports with the theory of accomplice liability and with the legislative purpose of the CCE offense. It also preserves the general structure of sentencing in the drug laws. The optimal solution to the problem of CCE accomplice liability, therefore, is to impose liability only when the defendant has intentionally aided the kingpin's supervision of the CCE.

${ }^{128}$ However, one could argue that $\mathrm{X}$ has only aided the daily operations of the organization, not necessarily $Y$ 's leadership of it. Whether or not particular types of aid are aid to the kingpin's leadership would be a fact question for the jury to decide. 